\title{
Quality characteristics of tea of Tenebrio molitor larvae according to manufacturing methods
}

\author{
Jinho Woo ${ }^{1}$, Hyeonjeong Lee ${ }^{2}$, Jiyoung $\mathrm{Choi}^{1}$, Kwangdeog Moon ${ }^{1,2 *}$ \\ ${ }^{1}$ Food and Bio-industry Research institute, Kyungpook National University, Daegu 41566, Korea \\ ${ }^{2}$ Department of Food Science and Biotechnology, Kyungpook National University, Daegu 41566, Korea
}

\section{제조 방법에 따른 갈색거저리 유충 차의 품질특성}

\author{
우진호 $^{1} \cdot$ 이현정 $^{2} \cdot$ 최지 영 $^{2} \cdot$ 문광덕 $^{1,2 *}$ \\ ${ }^{1}$ 경북대학교 식품생물산업연구소, ${ }^{2}$ 경북대학교 식품공학과
}

\begin{abstract}
The purpose of this study was to expand the possibility Tenebrio molitor larvae as a food material. Different types of tea were produced using microwaved Tenebrio molitor $\mathrm{L}$., and the quality characteristics were analyzed. Leached tea (T1) was prepared by leaching the crushed microwaved larvae. Liquid tea (T2) was prepared by first extracting the crushed larvae with distilled water and then diluting it. To prepare the solid tea (T3), dextrin was added to the extract, which was then spray-dried and dissolved in distilled water. Amino acid contents, $\mathrm{pH}$, soluble solids, transmittance, color, and sensory properties were examined to evaluate the quality characteristics of the three types of tea. It was revealed that the total amino acid was abundant in $T 1(277.76 \mathrm{mg} / \mathrm{g})$, and the proline content was the highest in all the teas. The $\mathrm{pH}$ of $\mathrm{T3}$ was 6.58 , which was significantly the lowest among $\mathrm{T} 1, \mathrm{~T} 2$, and $\mathrm{T3}$. T3 had the highest content of soluble solids $\left(5.33{ }^{\circ} \mathrm{Brix}\right)$ and highest transmittance $(37.33 \%)$. The analysis of color values revealed that the $L^{*}$ (lightness) value of $T 1$ was the highest $(50.92)$, while the a (redness) values of $T 1$, $T 2$, and $T 3$ were similar $\left(-0.42,-0.18\right.$, and 0.64 , respectively). The $b^{*}$ (yellowness) value of $T 3$ was the highest (6.47). The sensory evaluations revealed that $\mathrm{T} 1$ was significantly superior in color, flavor, umami taste, and overall acceptability. Turbidity, sweetness, and saltiness of the three teas were not significantly different. Overall, the quality characteristics of $\mathbf{A}$ are the best.
\end{abstract}

Key words : Tenebrio molitor larvae, tea, quality characteristics, amino acid contents, sensory evaluation

\section{서 론}

식용곤충(edible insect)이란 식용을 목적으로 하는 곤충 을 뜻하며 나비목(Lepidoptera), 딱정벌레목(Coleoptera), 메 뚜기목(Orthoptera), 흰개미목(Isoptera)과 벌목(Hymenoptera) 등이 있다(1). 곤충을 섭취하는 지역으로는 토고, 앙골라, 짐바브웨, 마다가스카르, 멕시코, 브라질, 인도, 이탈리아,

*Corresponding author. E-mail : kdmoon@ @nu.ac.kr Phone : 82-53-950-5773, Fax : 82-53-950-5772

Received 30 October 2018; Revised 03 December 2018; Accepted 13 December 2018.

Copyright (c) The Korean Society of Food Preservation. All rights reserved.
중국, 일본, 한국 등이 있으며, 곤충을 섭취하는 이유는 개발 도상국의 경우에는 부족한 단백질원을 보충하기 위한 목적 으로, 선진국에서는 전통식품의 하나로 섭취되고 있다 $(2,3)$.

식용곤충은 사육 시 소나 돼지 등의 가축보다 이산화탄 소 $\left(\mathrm{CO}_{2}\right)$, 아산화질소 $\left(\mathrm{N}_{2} \mathrm{O}\right)$, 메탄 $\left(\mathrm{CH}_{4}\right)$, 암모니아 $\left(\mathrm{NH}_{3}\right)$ 가스 의 방출량이 현저히 적으며(4), 사육에 요구되는 사료량도 가축의 $1 / 10$ 밖에 되지 않는다. 또한 전세계 농경지의 $70 \%$ 가 가축의 사육에 이용되고 있을 만큼 넓은 사육면적을 요구하 는데 반해 식용곤충 사육시에는 좁은 면적에서 고도로 밀집 된 시설을 이용하므로 식용곤충은 친환경적인 미래 식품소 재라 할 수 있다.

곤충의 일반성분은 조단백질 $30-70 \%$, 조지방 $4-50 \%$ 를 
함유하고 있어 종에 따라 다양한 함량분포를 보인다(5). 그중 갈색거저리 유충(Tenebrio molitor larvae)은 건조중량 중 조단백질이 약 $50 \%$, 조지방이 약 $30 \%$ 함유되어 있을 뿐만 아니라 비타민, 무기질 성분도 풍부하게 함유되어 있 다(6).

이처럼 갈색거저리를 비롯한 식용곤충이 단백질과 지질 을 많이 함유하고 있어 영양적인 측면에서 우수하고 사육시 오염물질 배출이 적다는 장점이 있음에도 서구사회에서 곤충에 대한 인식은 농작물에 피해를 입히고 목재 구조물을 훼손하며 질병을 매개하는 부정적인 이미지가 확고히 자리 잡고 있다. 이러한 이유로 곤충과 곤충식이에 대해 편견과 혐오감을 가지고 있는 것이 현실이다(7). 현재 우리나라에 서도 벼메뚜기(Oxya japonica), 누에(Bombyx mori larva)와 누에번데기(Bombyx mori pupa), 백강잠, 쌍별귀뚜라미 (Gryllus bimaculatus), 장수풍뎅이 유충(Allomyrina dichotoma larva), 흰점박이꽃무지 유충(Protaetia brevitarsis larva), 갈 색거저리 유충(Tenebrio molitor larva)이 정식으로 식품원 료로 등록되어 누구나 식용으로 유통-판매가 가능하게 되 었지만, 곤충과 곤충식이에 대한 부정적인 인식으로 인해 이용도는 낮은 상황이다.

현재까지 갈색거저리 유충을 이용한 식품개발연구로는 갈색거저리 유충 분말을 이용하여 제조한 패티의 품질특성 연구(8), 갈색거저리 유충 분말을 이용하여 제조한 쿠키의 품질특성 연구(9), 갈색거저리를 첨가한 파스타의 품질특 성 연구(10), 갈색거저리 분말을 첨가한 머핀의 품질특성 연구(11) 등으로, 식용곤충 분말을 첨가하여 제조된 제품의 품질특성연구가 대부분인 실정이다.

따라서 본 연구에서는 갈색거저리 유충의 식품소재로서 의 활용가능성을 확대하고, 식용곤충에 대한 혐오감을 줄 이고자 액상 식품인 차(茶)를 제조하였고, 가공을 통해 침출 차, 액상차, 고형차를 제조하여 그 품질특성을 분석하였다.

\section{재료 및 방법}

\section{실험재료}

실험에서 사용된 갈색거저리 유충은 경상북도 구미시의 사육농가에서 습도 $60 \%$, 온도 $26 \pm 1{ }^{\circ} \mathrm{C}$ 조건에서 사육된 것 을 구입하였다. 유충은 몸체 길이 $23-28 \mathrm{~mm}$ 의 것을 선별하 였고, 2일간 절식시켰을 때 색, 향미, 기호도가 우수하다는 Chung 등(12)의 연구결과에 따라 2 일간 절식시킨 후 실험에 사용하였다.

\section{전처리}

절식시킨 유충은 세척 후 물기를 제거하여 deep freezer에 서 $-50^{\circ} \mathrm{C}$ 로 보관하였고, 실험에 앞서 해동하였다. 해동 후에 는 전자레인지(MWO20M7, SKmagic, Hwaseong, Korea)를
이용하여 70 초 동안 마이크로웨이브 처리한 후 차 제조에 이용하였다.

\section{차의 제조}

침출차(leached tea)는 거저리 유충을 막자사발로 파쇄하 여 티백(tea bag)에 담아 끓인 증류수에 우려내었다. 티백에 담긴 샘플의 양은 $0.5 \mathrm{~g}$ 이었고 증류수는 끓인 후 티백에 $20 \mathrm{~mL}$ 를 넣고 3분간 침출하였다.

액상차(liquid tea)는 거저리 유충의 추출물을 이용하여 제조하였다. 마이크로웨이브 처리 유충 무게의 10 배에 해 당하는 증류수를 첨가한 후 homogenizer(AM-9, Nihonseiki Kashima Co., Ltd., Osaka, Japen)를 이용하여 10,000 rpm에 서 1 분간 분쇄하고, 환류추출장치를 이용하여 열수추출하 였다. 추출조건은 예비실험을 통하여 $66^{\circ} \mathrm{C}, 7$ 시간으로 설정 하였고, 추출 후 여과한 추출물과 끓인 증류수를 1:1의 비율 로 희석하여 액상차를 제조하였다.

고형차(solid tea)는 액상차 제조와 같은 방법으로 추출 및 여과한 여과액을 분무건조하여 제조하였다. 분말화를 위하여 추출물에 덱스트린을 첨가하여 30 분간 균질화하여 혼합용액을 제조하였고, 이때 혼합용액의 가용성 고형분 함량은 $14{ }^{\circ} \mathrm{Brix}$ 였다. 제조된 용액은 $2 \mathrm{~mL} / \mathrm{min}$ 의 속도로 분무건조기(KL-8, Seo Gang Engineering Co., Ltd., Cheonan, Korea)로 주입하였고, 건조 조건은 주입구 온도 $150^{\circ} \mathrm{C}$, 투입 구 온도 $100^{\circ} \mathrm{C}$ 로 설정하였다. 고형차는 제조된 분말에 분말 무게의 20 배에 해당하는 부피의 끓인 증류수를 첨가하여 제조하였다.

\section{일반성분}

갈색거저리 유충의 수분함량, 조지방, 조단백질, 조회분 은 식품공전(13)에 준하여 분석하였다. 수분함량은 dry oven(KMC-1202D3, Vision Scientific Co., Daejeon, Korea) 을 이용하여 $105^{\circ} \mathrm{C}$ 상압가열건조법에 준하여 실시하였다. 조지방은 ether 추출법, 조회분은 $600^{\circ} \mathrm{C}$ 의 온도에서 직접회 화법으로 분석하였고, 조단백질은 Kjeldahl 질소정량법으 로 분석한 후 질소계수 6.25 를 적용하여 구하였다.

\section{미량원소}

미량원소를 분석하기 위하여 갈색거저리 유충을 $-50^{\circ} \mathrm{C}$ 에 서 24시간 동안 보관하여 희생시킨 후 동결건조 (freeze-dried)하였다. 건조된 시료를 분쇄하여 $0.3 \mathrm{~g}$ 을 취하 고 $70 \% \mathrm{HNO}_{3} 5 \mathrm{~mL}$ 와 $\mathrm{H}_{2} \mathrm{O}_{2} 0.5 \mathrm{~mL}$ 를 첨가한 후 microwave 처리를 통해 분해하였다. Microwave 처리는 $220^{\circ} \mathrm{C}, 110 \mathrm{bar}$ 에서 $1,500 \mathrm{~W}$ 출력으로 25 분간 진행하였고, 분해된 시료에 $2 \%$ 질산을 넣어 묽힌 후 inductively coupled plasma spectrometer(Optima 7300DV, PerkinElmer Inc., New York, $\mathrm{NY}, \mathrm{USA}$ )를 이용하여 $\mathrm{Fe}, \mathrm{Zn}, \mathrm{Na}, \mathrm{Mg}, \mathrm{Ca}, \mathrm{K}, \mathrm{Mn}, \mathrm{Cu}$, $\mathrm{P}$ 의 함량을 분석하였다. 


\section{구성아미노산 함량}

차제품의 구성 아미노산 분석을 위해 샘플 $50 \mathrm{mg}$ 에 1 $\mathrm{mL}$ 의 $6 \mathrm{~N} \mathrm{HCl}$ 을 넣고 질소가스를 1 분간 충진하여 밀봉한 후 $110^{\circ} \mathrm{C}$ 에서 24 시간 동안 가수분해하였다. 이후 뚜껑을 열고 $80^{\circ} \mathrm{C}$ 로 낮추어 24 시간 방치하여 건조시킨 후 $1 \mathrm{~mL}$ 의 $0.2 \mathrm{~N} \mathrm{HCl}$ 을 넣고 vortexing과 sonicating을 수 회 반복하여 건조물을 완전히 녹여 $0.45 \mu \mathrm{m}$ syringe filter로 여과하였고, 여과된 시료를 amino acid analyzer(L-8900, Hitachi, Tokyo, Japan)를 이용하여 18 종에 해당하는 구성아미노산을 분석 하였다.

\section{$\mathrm{pH}$, 가용성 고형분, 투과도}

pH는 $\mathrm{pH}$ meter(Orion 3 star, Thermo Electron Co, Waltham, MA, USA)를 이용하여 측정하였고, 가용성 고형 분 함량은 굴절당도계(Master-a, Atago Co., Tokyo, Japan)를 이용하여 분석하였다. 투과도는 입사광의 강도에 대한 투 과광의 강도로 나타내기 위하여 아래의 식을 이용하였다. Abs값은 UV-visible spectrophotometer(Optizen ${ }^{\mathrm{TM}}$ POP, Meacasys, Daejeon, Korea)을 이용하여 $600 \mathrm{~nm}$ 에서 흡광도를 측정하 여 구하였다.

$\%$ Transmittance $=10^{-\mathrm{Abs}} \times 100$

\section{색 도}

차제품의 색도는 colorimeter(CR-400, Konica Minolta Co., Osaka, Japan)을 이용하여 CIE L*(lightness), $\mathrm{a}^{*}$ (redness), $\mathrm{b}^{*}$ (yellowness) 값을 측정하였다. 샘플은 $5 \mathrm{~mL}$ 씩 채취하여 직경 $3.5 \mathrm{~cm}$ petri dish에 담아 백색판 위에서 측정 하였고, 실험에 앞서 표준 백색판 $\left(\mathrm{L}^{*}=97.79, \mathrm{a}^{*}=-0.38\right.$, $\left.\mathrm{b}^{*}=2.05\right)$ 으로 보정한 후 측정하였다.

\section{관능검사}

마이크로웨이브 처리한 갈색거저리 유충 차제품의 관능 검사는 경북대학교 식품공학과 학생 16 명을 대상으로 실시 하였다. 색(color), 탁도(turbidity), 향(flavor), 고소한 맛 (umami taste), 단맛(sweetness), 짠맛(saltiness), 전반적 기호 도(overall acceptability) 항목을 선호도에 따라 7점 척도법 으로 평가하였으며 평가에 앞서 경북대학교 생명윤리심의 위원회의 IRB 승인을 받은 후 진행하였다(IRB 승인번호: 2017-0123).

\section{통계분석}

구성아미노산을 제외한 모든 실험결과는 3회 이상 반복 측정하였고, 평균과 표준편차를 statistical analysis system program(SAS 9.4, SAS Institute Inc., Cary, NC, USA)을 이용 하여 나타내었다. 실험구 간의 유의성 판별은 Duncan's multiple range test를 통하여 $\mathrm{p}<0.05$ 수준에서 유의성 검정 을 하였다.

\section{결과 및 고찰}

\section{일반성분}

본 실험에서 사용된 거저리 유충의 수분함량, 조지방, 조단백질, 조회분 분석 결과를 Table 1 에 나타내었다. 수분 함량은 $57.13 \%$, 조지방은 $10.63 \%$, 조단백질은 $22.28 \%$, 조 회분은 $2.03 \%$, 탄수화물은 $7.93 \%$ 로 Kim 등(14)의 연구와 유사한 결과를 보였다.

Table 1. The proximate compounds of Tenebrio molitor larvae

\begin{tabular}{cc}
\hline Common ingredient & Contents $(\%, w / w)$ \\
\hline Moisture & $57.13 \pm 0.61^{1)}$ \\
Crude fat & $10.63 \pm 0.19$ \\
Crude protein & $22.28 \pm 0.19$ \\
Crude ash & $2.03 \pm 0.27$ \\
Carbohydrate $^{2)}$ & $7.93 \pm 0.69$ \\
\hline
\end{tabular}

${ }^{1)}$ Values are mean $\pm \mathrm{SD}(\mathrm{n}=3)$.

${ }^{2)}$ Carbohydrate $=100$-(moisture+crude fat + crude protein + crude ash $)$.

\section{미량원소}

갈색거저리 유충의 미량원소는 $\mathrm{Fe}, \mathrm{Zn}, \mathrm{Na}, \mathrm{Mg}, \mathrm{Ca}, \mathrm{K}$, $\mathrm{Mn}, \mathrm{Cu}, \mathrm{P}$ 8종을 분석하여 Table 2에 나타내었다. 미량원소 분석 결과 $\mathrm{Fe} 92.81 \mathrm{mg} / \mathrm{L}, \mathrm{Zn} 155.31 \mathrm{mg} / \mathrm{L}, \mathrm{Na} 815.78 \mathrm{mg} / \mathrm{L}$, $\mathrm{Mg} 4,895.76 \mathrm{mg} / \mathrm{L}, \mathrm{Ca} 397.70 \mathrm{mg} / \mathrm{L}, \mathrm{K}$ 7,410.14 mg/L, Mn $12.92 \mathrm{mg} / \mathrm{L}, \mathrm{Cu} 25.19 \mathrm{mg} / \mathrm{L}, \mathrm{P} 9,530.56 \mathrm{mg} / \mathrm{L}$ 으로 나타났다. 이러한 결과는 Finke(15)의 연구와 대체로 차이가 있었으 나, Ravzanaadii 등(16)의 연구와 비교하였을 때는 $\mathrm{Ca}, \mathrm{P}$, $\mathrm{K}, \mathrm{Fe}$ 는 유사하였고, $\mathrm{Na}, \mathrm{Mg}, \mathrm{Zn}, \mathrm{Cu}$ 는 다소 차이를 보였다.

Table 2. The mineral contents of Tenebrio molitor larvae

\begin{tabular}{cc}
\hline Mineral & Contents $(\mathrm{mg} / \mathrm{L})$ \\
\hline Iron & $92.81 \pm 4.25^{1)}$ \\
Zinc & $155.31 \pm 3.20$ \\
Sodium & $815.78 \pm 6.20$ \\
Magmesium & $4,895.76 \pm 91.57$ \\
Calcium & $397.70 \pm 7.57$ \\
Potassium & $7,410.14 \pm 82.28$ \\
Manganese & $12.92 \pm 0.19$ \\
Copper & $25.19 \pm 0.38$ \\
Phosphorus & $9,530.56 \pm 95.93$ \\
\hline
\end{tabular}

${ }^{1)}$ Values represent mean $\pm \mathrm{SD}(\mathrm{n}=4)$.

\section{구성아미노산 함량}

갈색거저리 유충 차의 구성아미노산 함량은 Table 3 과 같다. 총 구성아미노산 함량은 침출차 $277.76 \mathrm{mg} / \mathrm{g}$, 액상차 $106.28 \mathrm{mg} / \mathrm{g}$, 고형차 $15.51 \mathrm{mg} / \mathrm{g}$ 으로 큰 차이를 보였고 모든 
차에서 proline 함량이 가장 높은 것으로 나타났다. Finke(15)의 갈색거저리 유충의 성분분석 결과(glutamic acid $21.1 \mathrm{~g} / \mathrm{kg}$, proline $13.0 \mathrm{~g} / \mathrm{kg}$ )와 Yoo 등(17)의 국산 및 중국산 갈색거저리 유충의 성분분석 결과(국산: glutamic acid $6.59 \%$, proline $3.15 \%$, 중국산: glutamic acid $6.61 \%$, proline $3.66 \%$ )에서는 glutamic aicd의 함량이 proline의 함량 보다 높은 것으로 보고하고 있다. 이러한 차이는 전처리 과정 중 마이크로웨이브처리에 의한 단백질 변화에 기인한 것으로 사료된다(18). Proline 다음으로 함량이 높은 아미노 산은 침출차의 경우 glutamic acid였고, 액상차와 고형차는 alanine인 것으로 나타났다. Proline과 alanine을 살펴보면 침출차와 액상차는 비슷한 함량(\%)을 보였으나 고형차는 다른 두 차에 비해 높은 함량을 보였다. 이러한 아미노산 함량의 차이는 제조과정에서 가해진 열에 의한 것으로 사료 된다. Lee 등(19)의 연구에 따르면 추출온도가 $125-175^{\circ} \mathrm{C}$ 인 구간에서는 추출되는 glutamic acid의 함량은 온도가 올라 갈수록 낮아지는 경향을 보였고, alanine의 함량은 높아지 는 경향을 보였다. 이러한 추출조건에 따른 아미노산의 함 량의 변화는 추출온도와 추출압력에 따른 아미노산의 손상 에 기인한 것으로 판단하고 있는데, 본 연구에서도 고형차 를 제조하는 과정에서 분무건조로 인한 열에너지가 아미노
산에 손상을 주어 침출차, 액상차와는 다른 양상을 보인다 고 사료된다.

침출차의 필수아미노산:비필수아미노산 비율은 34.65:65.35, 액상차의 경우는 36.48:63.52로 나타났다(data not shown). 이는 Ghosh 등(20)의 연구에서 갈색거저리 유충의 필수/비 필수아미노산의 비율(37.51:62.4)과 유사한 값으로 나타났 다. 고형차의 경우는 28.57:71.43으로 나타났고 이 또한 열 손상에 기인한 것으로 사료된다.

\section{$\mathrm{pH}$, 가용성 고형분, 투과도}

갈색거저리 유충을 이용하여 제조한 차의 $\mathrm{pH}$, 가용성 고형분, 투과도 결과는 Table 4에 나타내었다. $\mathrm{pH}$ 는 고형차 가 6.58로 가장 낮은 값으로 나타났고, 침출차, 액상차가 $6.91,7.00$ 으로 높은 값을 보였으며 차의 종류에 따른 유의 적 차이가 있었다. 가용성 고형분은 고형차가 $5.33{ }^{\circ} \mathrm{Brix}$ 로 가장 높게 나타났고, 액상차, 침출차가 $0.97,0.50{ }^{\circ} \mathrm{Brix}$ 로 상대적으로 낮게 나타났다. 이는 고형차 분말의 제조시 첨 가된 덱스트린의 영향으로 사료된다. $600 \mathrm{~nm}$ 에서 측정한 투과도는 침출차가 $37.33 \%$ 으로 가장 높게 나타났고, 고형 차, 액상차는 $1.11,0.25 \%$ 로 낮은 투과도를 보였다.

Table 3. Total amino acid contents of leached tea, liquid tea and solid tea processed from Tenebrio molitor larvae

\begin{tabular}{|c|c|c|c|c|c|c|c|}
\hline & \multirow[b]{2}{*}{ Amino acid } & \multicolumn{2}{|c|}{ Leached tea ${ }^{1)}$} & \multicolumn{2}{|c|}{ Liquid tea ${ }^{2}$} & \multicolumn{2}{|c|}{ Solid tea ${ }^{3)}$} \\
\hline & & $\mathrm{mg} / \mathrm{g}$ & $\% \%^{4)}$ & $\mathrm{mg} / \mathrm{g}$ & $\%$ & $\mathrm{mg} / \mathrm{g}$ & $\%$ \\
\hline \multirow{8}{*}{$\begin{array}{l}\text { Essential } \\
\text { amino acid }\end{array}$} & Threonine & 8.51 & 3.06 & 3.65 & 3.43 & 0.36 & 2.32 \\
\hline & Valine & 16.29 & 5.87 & 6.77 & 6.37 & 1.01 & 6.48 \\
\hline & Methionine & 2.97 & 1.07 & 1.03 & 0.97 & 0.07 & 0.47 \\
\hline & Isoleucine & 9.78 & 3.52 & 4.11 & 3.87 & 0.56 & 3.64 \\
\hline & leucine & 13.63 & 4.91 & 5.01 & 4.71 & 0.69 & 4.44 \\
\hline & Phenylalanine & 9.62 & 3.46 & 3.02 & 2.84 & 0.42 & 2.70 \\
\hline & Lysine & 19.89 & 7.16 & 9.01 & 8.48 & 0.79 & 5.11 \\
\hline & Histidine & 15.55 & 5.60 & 6.17 & 5.80 & 0.53 & 3.41 \\
\hline \multirow{10}{*}{$\begin{array}{l}\text { Non-essential } \\
\text { amino acid }\end{array}$} & Aspartic acid & 15.90 & 5.72 & 5.76 & 5.42 & 0.74 & 4.75 \\
\hline & Serine & 7.29 & 2.62 & 2.98 & 2.81 & 0.35 & 2.24 \\
\hline & Glutamic acid & 29.73 & 10.70 & 9.39 & 8.84 & 1.92 & 12.37 \\
\hline & Glycine & 13.97 & 5.03 & 5.50 & 5.17 & 0.40 & 2.57 \\
\hline & Alanine & 27.69 & 9.97 & 10.66 & 10.03 & 2.44 & 15.71 \\
\hline & Cystine & 2.91 & 1.05 & 1.28 & 1.20 & 0.07 & 0.43 \\
\hline & Tyrosine & 18.99 & 6.84 & 7.63 & 7.18 & 0.76 & 4.89 \\
\hline & Arginine & 18.90 & 6.81 & 7.12 & 6.70 & 1.11 & 7.19 \\
\hline & Proline & 46.14 & 16.61 & 17.19 & 16.17 & 3.30 & 21.28 \\
\hline & Total & 277.76 & 100.00 & 106.28 & 100.00 & 15.51 & 100.00 \\
\hline
\end{tabular}

${ }^{1)}$ Leached tea is produced by leaching microwave treated Tenebrio molitor $\mathrm{L}$.

${ }^{2}$ Liquid tea is prepared by diluting the extract of microwave treated Tenebrio molitor $\mathrm{L}$.

${ }^{3}$ Solid tea is prepared by dissolving the spray dried powder of extract.

${ }^{4)}$ (Amino acid/Total amino acid) $\times 100$ 


\section{색 도}

갈색거저리 유충을 이용하여 제조된 차의 $\mathrm{L}^{*}, \mathrm{a}^{*}, \mathrm{~b}^{*}$ 값은 Table 5 에 제시하였다. $\mathrm{L}^{*}$ 값은 침출차가 50.92 로 가장 높은 값을 나타내었고, $\mathrm{a}^{*}$ 값은 침출차 -0.42 , 액상차 -0.18 , 고형 차 0.64 로 유의적 차이는 나타났으나 절대값의 차이는 적었 다. $\mathrm{b}^{*}$ 값은 침출차 5.53 , 액상차 4.15 , 고형차 6.47 로 고형차 가 가장 높게 나타났다. 종합하여 볼 때, 전반적으로 값의 차이는 미미하였으나 차의 형태에 따른 유의적 차이는 뚜렷 하게 나타난 것을 확인하였다.

Table 4. pH, soluble solid, \% Transmittance of leached tea, liquid tea and solid tea processed from Tenebrio molitor larvae

\begin{tabular}{cccc}
\hline & $\mathrm{pH}$ & Soluble solid ( ${ }^{\circ}$ Brix) & \% Transmittance \\
\hline Leached tea $^{\mathrm{l})}$ & $6.91 \pm 0.01^{4 \mathrm{~b} 5)}$ & $0.50 \pm 0.00^{\mathrm{c}}$ & $37.33 \pm 0.34^{\mathrm{a}}$ \\
Liquid tea $^{2)}$ & $7.00 \pm 0.04^{\mathrm{a}}$ & $0.97 \pm 0.06^{\mathrm{b}}$ & $0.25 \pm 0.00^{\mathrm{c}}$ \\
Solid tea $^{3)}$ & $6.58 \pm 0.02^{\mathrm{c}}$ & $5.33 \pm 0.06^{\mathrm{a}}$ & $1.11 \pm 0.00^{\mathrm{b}}$ \\
\hline
\end{tabular}

${ }^{1)}$ Leached tea is produced by leaching microwave treated Tenebrio molitor $\mathrm{L}$.

${ }^{2}$ Liquid tea is prepared by diluting the extract of microwave treated Tenebrio molitor L.

${ }^{3)}$ Solid tea is prepared by dissolving the spray dried powder of extract.

${ }^{4)}$ Values represent mean $\pm S D(n=3)$.

${ }^{5) a-c}$ Values with different superscript within the column are significantly different by Duncan's multiple range test $(\mathrm{p}<0.05)$.

Table 5. Color value of leached tea, liquid tea and solid tea processed from Tenebrio molitor larvae

\begin{tabular}{cccc}
\hline & $\mathrm{L}^{*}$ & $\mathrm{a}^{*}$ & $\mathrm{~b}^{*}$ \\
\hline Leached tea $^{\mathrm{k}}$ & $50.92 \pm 0.34^{4 \mathrm{a} 5)}$ & $-0.42 \pm 0.03^{\mathrm{c}}$ & $5.53 \pm 0.18^{\mathrm{b}}$ \\
Liquid tea $^{2)}$ & $41.55 \pm 0.34^{\mathrm{b}}$ & $-0.18 \pm 0.07^{\mathrm{b}}$ & $4.15 \pm 0.11^{\mathrm{c}}$ \\
Solid tea $^{3)}$ & $40.15 \pm 0.49^{\mathrm{c}}$ & $0.64 \pm 0.05^{\mathrm{a}}$ & $6.47 \pm 0.21^{\mathrm{a}}$ \\
\hline
\end{tabular}

${ }^{1)}$ Leached tea is produced by leaching microwave treated Tenebrio molitor $\mathrm{L}$.

${ }^{2}$ Liquid tea is prepared by diluting the extract of microwave treated Tenebrio molitor L.

${ }^{3}$ Solid tea is prepared by dissolving the spray dried powder of extract.

${ }^{4}$ Values represent mean $\pm \mathrm{SD}(\mathrm{n}=3)$.

5)a-b Values with different superscript within the column are significantly different by Duncan's multiple range test $(\mathrm{p}<0.05)$.

\section{관능검사}

갈색거저리 유충을 이용하여 제조된 차의 관능검사 결과 는 Table 6에 제시된 바와 같다. 색에 대한 기호도는 침출차
가 6.06으로 가장 높았고, 액상차가 4.06으로 가장 낮은 값을 보였다. 탁도의 경우, 침출차가 5.13으로 고형차, 액상 차에 비해 높은 선호도를 보였으나 유의적인 차이를 보이지 는 않았다. Table 4에서 침출차의 투과도가 다른 차에 비해 월등히 높았으나 기호도에 큰 영향을 주지는 않은 것으로 보인다. 향은 액상차가 5.50으로 침출차 5.31에 비해 높은 선호도를 보였으나 유의적인 차이는 없었고, 고형차가 4.13 으로 가장 낮은 선호도를 보였다. 고소한맛의 경우는 침출 차가 5.38로 다른 차에 비해 높은 선호를 보였다. 이는 고소 한맛과 glutamic acid가 크게 연관이 있다고 알려진바 있으 며(21), Table 3의 아미노산 결과에서 총 아미노산 함량을 고려한 glutamic acid 함량이 침출차가 가장 높다는 점으로 보아 glutamic acid 함량이 선호도에 반영된 것으로 사료된 다. 단맛, 짠맛은 차의 형태에 따른 차이는 있었으나 유의적 인 차이를 보이지는 않았다. 종합적 기호도는 침출차가 5.69 로 가장 높은 점수를 보였다. 다시 말해, 향, 고소한맛, 종합적 기호도에서 침출차가 유의적으로 높은 선호도를 보였고 탁도, 단맛, 짠맛은 차의 형태에 따른 차이를 보이지 않았다.

\section{요 약}

영양적으로 우수한 갈색거저리 유충을 이용하여 다양한 형태의 차를 제조하여 그 품질특성을 분석하였다. 실험에 사용된 거저리 유충의 일반성분을 분석한 결과 수분함량은 $57.13 \%$, 조지방은 $10.63 \%$, 조단백질은 $22.28 \%$, 조회분은 $2.03 \%$, 탄수화물은 $7.93 \%$ 로 나타났고, 미량원소는 $\mathrm{Fe} 92.81$ $\mathrm{mg} / \mathrm{L}, \mathrm{Zn} 155.31 \mathrm{mg} / \mathrm{L}, \mathrm{Na} 815.78 \mathrm{mg} / \mathrm{L}, \mathrm{Mg} 4,895.76 \mathrm{mg} / \mathrm{L}$, Ca $397.70 \mathrm{mg} / \mathrm{L}, \mathrm{K} 7,410.14 \mathrm{mg} / \mathrm{L}$, Mn $12.92 \mathrm{mg} / \mathrm{L}$, Cu 25.19 $\mathrm{mg} / \mathrm{L}, \mathrm{P} 9,530.56 \mathrm{mg} / \mathrm{L}$ 로 나타났다. 구성아미노산의 총량은 침출차가 가장 높았으며 $(277.76 \mathrm{mg} / \mathrm{g})$ 모든 차에서 proline 이 가장 많이 검출되었다. $\mathrm{pH}$ 는 고형차가 가장 낮게 측정이 되었고(6.58), 가용성 고형분은 고형차가 가장 높았다(5.33 $\left.{ }^{\circ} \mathrm{Brix}\right)$. 투과도는 침출차가 가장 높았고(37.33\%), 액상차, 고형차는 투과도가 $1.11 \%$ 이하로 매우 낮았다. 색도의 경우, $\mathrm{L}^{*}$ 값은 침출차가 가장 높았으며(50.92), $\mathrm{a}^{*}$ 값은 모든 차가

Table 6. The results of sensory evaluation for leached tea, liquid tea and solid tea processed from Tenebrio molitor larvae

\begin{tabular}{cccccccc}
\hline & Color & Turbidity & Flavor & Umami taste & Sweetness & Saltiness & Overall acceptability \\
\hline Leached tea $^{1)}$ & $6.06 \pm 0.77^{4) a 5}$ & $5.13 \pm 1.41^{\mathrm{a}}$ & $5.31 \pm 1.40^{\mathrm{a}}$ & $5.38 \pm 1.26^{\mathrm{a}}$ & $4.56 \pm 1.50^{\mathrm{a}}$ & $4.19 \pm 1.87^{\mathrm{a}}$ & $5.69 \pm 1.14^{\mathrm{a}}$ \\
Liquid tea $^{2)}$ & $4.06 \pm 1.29^{\mathrm{c}}$ & $4.50 \pm 1.59^{\mathrm{a}}$ & $5.50 \pm 0.89^{\mathrm{a}}$ & $4.44 \pm 1.03^{\mathrm{b}}$ & $4.44 \pm 1.55^{\mathrm{a}}$ & $4.00 \pm 1.21^{\mathrm{a}}$ & $4.50 \pm 1.15^{\mathrm{b}}$ \\
Solid tea $^{3)}$ & $4.88 \pm 1.02^{\mathrm{b}}$ & $4.50 \pm 1.10^{\mathrm{a}}$ & $4.13 \pm 1.20^{\mathrm{b}}$ & $4.25 \pm 1.34^{\mathrm{b}}$ & $4.13 \pm 1.41^{\mathrm{a}}$ & $3.69 \pm 1.20^{\mathrm{a}}$ & $4.25 \pm 1.29^{\mathrm{b}}$ \\
\hline
\end{tabular}

${ }^{1)}$ Leached tea is produced by leaching microwave treated Tenebrio molitor $\mathrm{L}$.

${ }^{2)}$ Liquid tea is prepared by diluting the extract of microwave treated Tenebrio molitor $\mathrm{L}$.

${ }^{3)}$ Solid tea is prepared by dissolving the spray dried powder of extract.

${ }^{4)}$ Values represent mean \pm SD $(n=3)$.

${ }^{5)-b}$ Values with different superscript within the column are significantly different by Duncan's multiple range test $(p<0.05)$ 
0 내외의 값을 보였고 $\mathrm{b}^{*}$ 값은 5 내외의 값을 나타내었다. 관능검사는 색, 향, 고소한맛, 종합적 기호도에서 침출차가 유의적으로 높은 점수를 보였다. 구성아미노산 함량과 관 능검사를 종합한 결과 갈색거저리 유충을 차로 제조할 경우 에는 침출차, 액상차, 고형차 중에서 침출차의 형태가 가장 적합할 것으로 판단된다.

\section{References}

1. Hwang SY, Bae G, Choi SK (2015) Preferences and purchase intention of Tenebrio molitor (mealworm) according to cooking method. Korean J Culinary Res, $21,100-115$

2. Jongema Y (2015) World list edible insects 2015. Wageningen University, Gelderland, Netherlands, 1-75

3. Bukkens SGF (1997) The nutritional value of edible insects. Ecol Food Nutr, 36, 287-319

4. Oonincx DGAB, van Itterbeeck J, Heetkamp MJW, van den Brand H, van Loon JJA, van Huis A (2010) An exploration on greenhouse gas and ammonia production by insect species suitable for animal or human consumption. Plos One, 5, e14445

5. Ramos-Elorduy J, Moreno JMP, Prado EE, Perez MA, Otero JL, de Guevara OL (1997) Nutritional value of edible insects from the state of Oaxaca, Mexico. J Food Compos Anal, 10, 142-157

6. Finke MD (2002) Complete nutrient composition of commercially raised invertebrates used as food for insectivores. Zoo Biol, 21, 269-285

7. van Huis $A$, Van Itterbeeck J, Klunder H, Mertens E, Halloran A, Muir G, Vantomme P (2013) Edible insects: future prospect for food and feed security. food and agriculture organization of the united nations, rome, italy, p 37-39

8. Kim HM, Kim JN, Kim JS, Jeong MY, Yun EY, Hwang JS, Kim AJ (2015) Quality characteristics of patty prepared with mealworm powder. Korean J Food Nutr, 28, 813-820

9. Min KT, Kang MS, Kim MJ, Lee SH, Han JS, Kim AJ (2016) Manufacture and quality evaluation of cookies prepared with mealworm (Tenebrio molitor) powder. Korean J Food Nutr, 29, 12-18
10. Kim SH, Kim KB, Noh JS, Yun EY, Choi SK (2014) Quality characteristics of pasta with addition of mealworm (Tenebrio molitor). FoodServ Ind J, 10, 55-64

11. Hwang SY, Choi SK (2015) Quality characteristics of muffins containing mealworm (Tenebrio molitor). Korean J Culinary Res, 21, 104-115

12. Chung MY, Kwon EY, Hwang JS, Goo TW, Yun EY (2013) Pre-treatment conditions on the powder of Tenebrio molitor for using as a novel food ingredient. J Seric Entomol Sci, 51, 9-14

13. KFDA, Food Code (2018) Korea Food and Drug Administration, Food Code. Seoul, Korea

14. Kim SY, Son YJ, Kim SH, Kim AN, Lee GY, Hwang IK (2015) Studies on oxidative stability of Tenebrio molitor larvae during cold storage. Korean J Food Cook Sci, 31, 62-71

15. Ravzanaadii N, Kim SH, Choi WH, Hong SJ, Kim NJ (2012) Nutritional value of mealworm, Tenebrio molitor as food source. Int J Indust Entomol, 25, 93-98

16. Yoo J, Hwang JS, Goo TW, Yun EY (2013) Comparative analysis of nutritional and harmful components in Korean and Chinese mealworms (Tenebrio molitor). J Korean Soc Food Sci Nutr, 42, 249-254

17. de Pomerai DI, Smith B, Dawe A, North K, Smith T, Archer DB, Duce IR, Jones D, Candido EPM (2003) Microwave radiation can alter protein conformation without bulk heating. FEBS Lett, 543, 93-97

18. Lee HJ, Saravana PS, Cho YN, Haq M, Chun BS (2018) Extraction of bioactive compounds from oyster (Crassostrea gigas) by pressurized hot water extraction. J Supercrit Fluids, 141, 120-127

19. Ghosh S, Lee SM, Jung C, Meyer-Rochow VB (2017) Nutritional composition of five commercial edible insects in South Korea. J Asia-Pac Entomol, 20, 686-694

20. Fuke S, Konosu S (1991) Taste-active components in some foods: A review of Japanese research. Physiol Behav, 49, 863-868 